\title{
Rapid Propagation of High-quality Garlic Seed-bulb Derived from Meristem-tips
}

\author{
Takayuki NAGAKUBO*, Miyuki TAKAICHI, Kenji OEDA and Hiromichi OSHIO \\ Biotechnology Laboratory, Sumitomo Chemical Co.Ltd., \\ 4-2-1 Takatsukasa, Takarazuka, Hyogo 665-8555, Japan. \\ *E-mail :
}

Received 28 December 1998; accepted 15 March 1999

\begin{abstract}
Conditions for rapid propagation of high- quality garlic seed-bulb derived from meristem-tips were investigated. Meristem-tips of garlic 'Howaito-roppen' were excised with or without a leaf primordium, and propagated to produce in vitro bulblets. Cloves were formed through one year of cultivation of the bulblets. Western blots for the obtained garlic plants indicated that meristem-tips without a leaf primordium to be a more suitable material to obtain healthy plants. Evaluation of clove formation could be performed on the column diameter at mid May. The clove formation depended on the size of the plant at the time of formation of clove initials. Plants without symptoms of virus were obtained irrespective of the size of the meristem-tips excised. However, some of the plants with no mosaic symptoms reacted with antiserum of garlic viruses, and portions of these plants increased when meristem-tips were cultured with leaf primordium. The resultant bulbs were cultivated in farmer's fields to investigate re-infected viruses. Sixty percent of the plants exhibited mosaic symptoms after 5 years of cultivation, the major viruses being LYSV and GMbMV. Re-infection was prevented by culturing bulbs in an isolated field.
\end{abstract}

\section{Introduction}

Commercial varieties of garlic (Allium sativum L.) are propagated through bulbs, and most of the plants are infected by viruses. Virus infected plants develop mosaic symptom on the leaves, and have reduced yield and smaller bulbs. Symptom-less plants can be obtained through meristem-tip culture and the resultant plants have better yield and quality (Ogawa et al., 1976; Bhojwani, 1980; Mikami, 1984; Walkey et al. 1987; Walkey and Antill, 1989; Novak, 1990; Conci and Nome 1991). However, viruses were detected with high frequency from meristem-tip derived plants when virus indexing was assesed using antisera(Walkey et al., 1987; Conci and Nome, 1991). Thus, studies of conditions for meristem-tip culture are needed, as are adequate methods for indexing of garlic viruses. A Number of viruses, including leek yellow stripe virus (LYSV)(Nagakubo et al, 1994), onion yellow dwarf virus (OYDV)(Kobayashi and Rabinowicz, 1996), carlaviruses (Lee et al., 1979; Abiko et al., 1980), and mite-borne viruses (van Dijk et al., 1991; Sumi et al., 1993; Yamashita et al., 1996) had been reported. However, indexing methods for each virus are limited.

Acclimatization of in vitro plants and raising the plants in the field is one of the critical steps for mass-propagation. Conditions for acclimatization of plantlets and bulblets have been reported (Bhojwani, 1980; Osawa and Sugawara, 1980; Walkey et al., 1987; Mori, 1988; Matsubara and Chen, 1989), but detailed information concerning conditions for raising the crop from in vitro materials is not available. Garlic planted in late September in the case of 'Howaito-roppen' is vernalized during winter, and is initiated for clove formation during April. Swelling of the clove initials is accelerated under conditions of high temperature and long day, and the resultant bulbs are harvested in early July. Bulblet plants less than a certain size produce a single cloved-bulb, instead of a multi-cloved normal bulb. Most reports described production of a single cloved bulb (Bhojwani, 1980; Pena-Igresias and Ayuso, 1982; Mori, 1988). There are few reports for production of multi-cloved bulbs (Walkey et al., 1987).

$\mathrm{Re}$-infection with viruses in the field is another serious problem. Propagation rate of garlic is basically very low being only 4 to 5 times per year in case of 'Howaito-roppen', the leading variety in 
Japan. Therefore, seed bulbs are repeatedly propagated for 5 or more years in the farmer's field, and the number of the diseased plants gradually increases during this period. The major viruses, which re-infect garlic plants derived from meristem-tips have not been well characterized hence suitable and practical methods for preventing re-infection have not been established.

We established an efficient method for micropropagation of in vitro bulblet(Nagakubo et al., 1993; Nagakubo et al., 1997). We could differentiate a variety of garlic viruses, such as three potyviruses, one carlavirus, and at least four mite-borne viruses. LYSV is apparently the major virus in this cultivar. We describe herein conditions for meristem-tip culture for virus elimination, cultivation of the meristem-tip derived bulblet, and also the propagation processes for the obtained bulbs in farmer's fields for up to 5 years.

\section{Materials and methods}

\subsection{Tissue culture conditions.}

Garlic 'Howaito-roppen' was used throughout the study. Tissue culture conditions have been described(Nagakubo et al., 1993; Nagakubo et al., 1997). Briefly, the meristem-tip was excised from cloves and cultured on LS medium with $1 \mu \mathrm{M}$ IAA and $1 \mu \mathrm{M}$ BA (meristem-tip culture medium; MC medium). Multiple shoots were induced on LS modified medium containing $56.5 \mathrm{mM} \mathrm{KNO}_{3}$ and $3.5 \mathrm{mM} \mathrm{NH}_{4} \mathrm{Cl}$, supplemented with $5 \mu \mathrm{M} \mathrm{NAA}$ and $10 \mu \mathrm{M}$ BA (shoot proliferation medium; SP medium). Multiple shoots were cultured on LS basal medium, then stored at $4{ }^{\circ} \mathrm{C}$ for 4 to 6 months (cold treatment). In vitro bulblets were produced by culturing cold-treated shoots on LS basal medium with $9 \%$ sucrose (bulbing medium).

\section{$2.2 R T-P C R$.}

Leaves of garlic plants were crushed in liquid nitrogen, total RNA was extracted with ISOGEN ${ }^{\mathrm{R}}$ (Nippon Gene), and the first strand of cDNA was synthesized from the total RNA solution, using First Strand cDNA synthesis Kit (Amersham). Oligonucleotide primers for amplification of LYSV, OYDV, GV1 carlavirus and mite-borne viruses were designed to amplify their CP genes, as described (Takaichi et al., 1998). The PCR reaction mixture with the cDNA preparation and the primers was subjected to 27 cycles of PCR. The resulting reaction mixtures were analyzed by agarose gel electrophoresis.

\subsection{Culture conditions in the field.}

Bulblets were planted into 200 - cell flats (cell size $2.8 \times 2.8 \times 4 \mathrm{~cm}$ ) filled with Metromix $350^{\circledR}$. The seedlings were grown in a vinyl house for 1 week under conditions of 50\% shading and for a further 3 weeks with no shading. Ambient air temperature was ca. $18-30^{\circ} \mathrm{C}$ during late August and September, in Aomori. Nursery stock was cultured in a insectproof house covered with Kuremona F-1000 vinylon transparent cheese cloth (Kurare, $0.95 \mathrm{~mm} \mathrm{x}$ $0.95 \mathrm{~mm}, 18 \%$ shading), in Misawa city, Aomori Prefecture. Fertilizer was applied at a rate of 200 $\mathrm{kg} / \mathrm{ha}$ for each of $\mathrm{N}, \mathrm{P}$ and $\mathrm{K}$. Planting was done into 5 -cm-diameter holes in 5 rows at $12 \mathrm{~cm}$ intervals in a black polyethylene-mulched bed (1.0 $\mathrm{m}$ wide and $0.15 \mathrm{~m}$ high).

Cloves were cultivated in our experimental field in Misawa, Aomori. The nearest field where traditional garlic is planted is located ca. $500 \mathrm{~m}$ away from this field.

\subsection{Western blots}

Young leaves of garlic plants grown in the screenhouse were homogenized in borate buffer $(0.1 \mathrm{M}$ $\mathrm{Na}_{2} \mathrm{~B}_{4} \mathrm{O}_{7}, \mathrm{pH}$ 8.0), and the crude extract was separated by centrifugation. The supernatant was sub jected to $12 \%$ SDS - polyacrylamide gel electrophoresis, and the resolved proteins were transferred onto nitrocellulose membranes (Schleicher and Schell, Dassel Germany). The membrane was exposed to an antiserum raised against garlic viruses from a rabbit (Nagakubo et al., 1997), and then to alkaline phosphatase conjugated anti-rabbit IgG from a goat (Jackson ImmunoResearch Laboratories, Inc.). Virus antigens on the membrane were visualized by reaction with 5-bromo-4-chloro-3indoryle phosphate and nitro blue tetrazolium.

\subsection{Diagnosis of mosaic symptom.}

Plants with mosaic symptoms (Fig. 1) were checked visually at mid May, a time when foliage growth of garlic is vigorous.

\section{Results}

3.1 Conditions of meristem-tip culture for in vitro multiplication and virus elimination

We prepared various sizes and forms of meristem - tips to determine the most suitable conditions for in vitro multiplication and virus elimination. Meristem-tips of garlic 'Howaito-roppen' were excised, without or with one leaf primordia and cultured on MC medium. Regenerated shoots from meristem-tips were transferred to SP medium and propagated for 5 cycles. After cold treatment, the proliferated shoots were cultured on the bulbing 


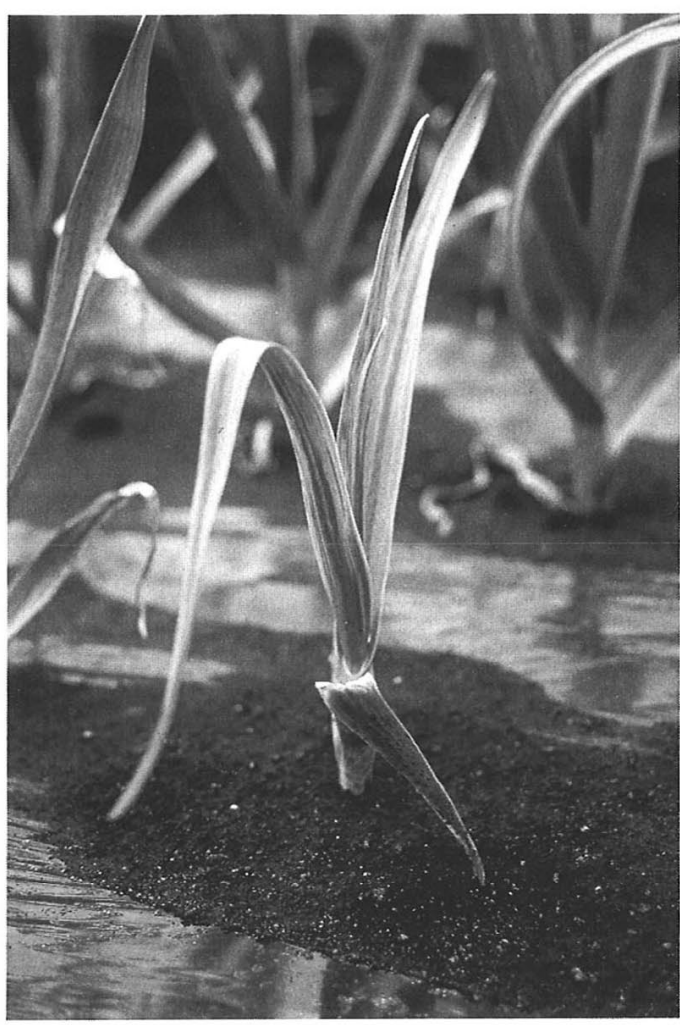

Fig. 1 Garlic plant with the severe mosaic symptom.

medium to produce bulblets. Eighty-five percent of meristem-tips became normal shoots on MC medium, and 104 bulblets, on average, were obtained from a meristem-tip without leaf primordium after 5 cycles-propagation. Ninety-four percent of meristem-tips regenerated shoots on MC medium, and on average 143 bulblets were obtained when meristem-tips with one leaf-primordium was cultured (Table 1).

\subsection{Evaluation of virus elimination}

In mid May, after 9 months of cultivation of the bulblets in an insect-proof house, development of virus symptoms was first investigated visually. Plants reached 40 to $50 \mathrm{~cm}$ in height and 4 to 6 viable leaves were present at this time. None of the plants exhibited the clear, yellowish mosaic symptom observed in field-grown garlic. However, some of the plants expressed slight mosaic symptoms. Rates of the symptom-less plants were $97 \%$ and $86 \%$, when meristem - tips were excised without, or with one leaf primordium, respectively. At the same time, virus was indexed based on Western-blots, using antiserum raised against garlic viruses. This antiserum can detect at least 3 potyviruses, including LYSV and OYDV, one carlavirus, and 4 miteborne viruses(Takaichi et al., in preparation). The results show that $93 \%$ and $68 \%$ of the plants were free of these viruses, when meristem-tips without or with one leaf primordium was cultured, respectively (Table 1).

\subsection{Evaluation of planting methods of bulblets for clove formation}

We tried to determine suitable conditions for transplantation of meristem-tip derived bulblets. Each of 100 bulblets weighing $150-500 \mathrm{mg}$ were planted on August 22nd and 29th, either into 200cell flats (cell seize $2.8 \times 2.8 \times 4 \mathrm{~cm}$ ) filled with Metromix $350^{\circledR}$ (transplanting), or were sown directly into the bed in the screenhouse (direct sowing). Nursery stock was transplanted into the same screenhouse after nursery care for four weeks in the greenhouse. On May 13th the next year, plant length, viable leaves, and column diameter of the plants were examined. Consequently, nursery stock planted on August 22nd was slightly larger than those planted on August 29th. Average column diameters of transplanted- and direct seeded-plants on August 22nd were $9.1 \mathrm{~mm}$ and $9.6 \mathrm{~mm}$, respectively, thus, a slightly better growth was obtained for plants started from direct sowing. Some of these plants were labeled, and the relationship between the column diameter and the clove number recorded. Multi-cloved bulbs were obtained with an efficiency rate higher in plants from cell-flats (34$35 \%)$ than those from direct sowing (13-21\%) (Table 2). Formation of the multi-cloved bulb was observed in plants over $>6 \mathrm{~mm}$ column in diameter on May 13 (Fig. 2). Most plants with the column of $>10 \mathrm{~mm}$ diameter formed multi-cloved bulbs.

Table 1. Effects of size of excised meristem on multiplication and virus- elimination

\begin{tabular}{cccccc}
\hline $\begin{array}{c}\text { No. of leaf } \\
\text { primordia }\end{array}$ & $\begin{array}{c}\text { No. of } \\
\text { meristemtips }\end{array}$ & $\begin{array}{c}\% \text { of } \\
\text { regeneration }\end{array}$ & $\begin{array}{c}\text { multiplication rate } \\
\text { (times) }\end{array}$ & $\begin{array}{c}\% \text { of virus-free } \\
\text { (western blot) }\end{array}$ & $\begin{array}{c}\% \text { of virus-free } \\
\text { (symptom) }\end{array}$ \\
\hline 0 & 70 & 85 & 104 & 93 & 97 \\
1 & 22 & 94 & 143 & 68 & 86 \\
\hline
\end{tabular}

Meristem-tips were cultured and propagated for 12 months to produce bulblets. These bulblets were seeded at late August, then planted in an insect-proof house in late September. Investigation of virus symptoms and leaf sampling for western blots was done in mid May. 
Table 2. Effects of planting methods of in vitro bulblet on clove formation

\begin{tabular}{|c|c|c|c|c|c|c|}
\hline \multirow[b]{2}{*}{ Method } & \multirow{2}{*}{$\begin{array}{l}\text { Date of } \\
\text { sowing }\end{array}$} & \multirow{2}{*}{$\begin{array}{c}\text { Date of } \\
\text { transplanting }\end{array}$} & \multicolumn{3}{|c|}{ Foliage growth at May 13} & \multirow{2}{*}{$\begin{array}{l}\% \text { clove } \\
\text { formation }\end{array}$} \\
\hline & & & $\begin{array}{l}\text { No. of } \\
\text { leaves }\end{array}$ & $\begin{array}{c}\text { Plant } \\
\text { length } \\
(\mathrm{cm})\end{array}$ & $\begin{array}{c}\text { Column } \\
\text { diameter } \\
(\mathrm{mm})\end{array}$ & \\
\hline Transplanting & Aug. 22 & Sep. 18 & $4.5 \pm 0.8$ & $47 \pm 7.4$ & $9.1 \pm 2.5$ & 34 \\
\hline Direct sowing & Aug. 22 & - & $4.9 \pm 1.0$ & $43 \pm 8.2$ & $9.6 \pm 3.1$ & 21 \\
\hline Transplanting & Aug. 29 & Sep. 26 & $4.3 \pm 0.6$ & $46 \pm 6.6$ & $8.2 \pm 1.7$ & 35 \\
\hline Direct sowing & Aug. 29 & - & $4.5 \pm 0.9$ & $41 \pm 7.9$ & $8.4 \pm 2.5$ & 13 \\
\hline
\end{tabular}

Each of 100 in vitro bulblets of $100-150 \mathrm{mg}$ was planted in a plastic tray (200 cells) and seedlings were transplanted (transplanting), or planted directly into the soil (direct sowing), on the dates shown. Each of 40 plants was selected at random, and parameters measured on May 13. Numbers of plants with cloves were scored at the time of harvest.

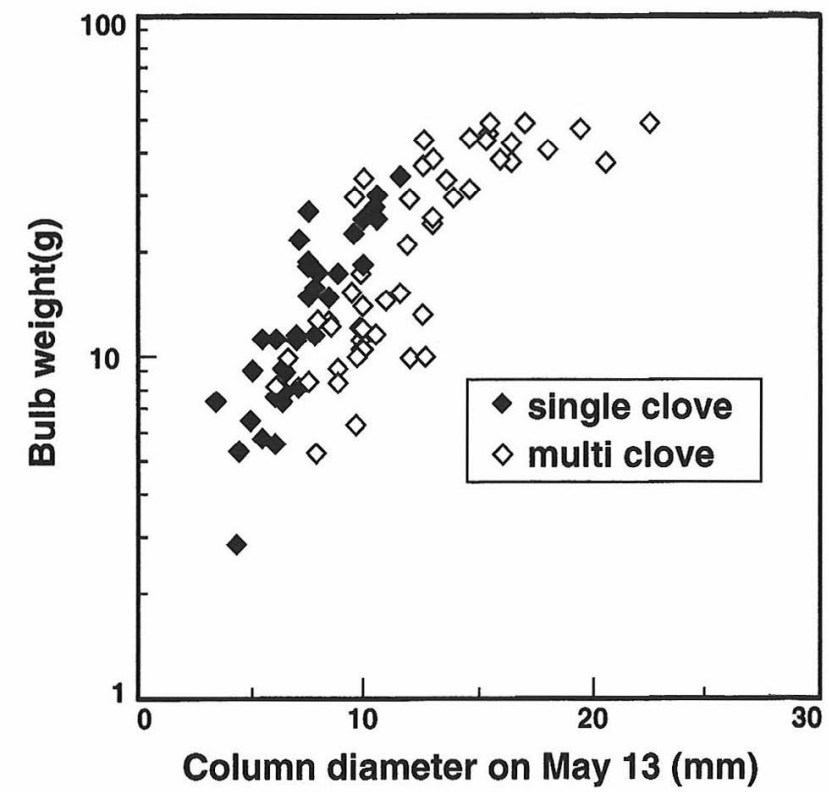

Fig. 2 Correlation between column diameter on May 13 , and type and weight of bulb harvested in plants derived from in vitro bulblets.

In vitro bulblets were cultivated, as shown in Table 2. Column diameters of the plants were measured on May 13.

Weight of the bulb correlated with the column diameter, and the maximum weight was $30 \mathrm{~g}$. Clove formation of bulblet-derived plants was initiated in late April in Aomori. Larger plants produce lateral buds (Fig. 3 A), which began swelling in early May (Fig. 3 B) and formed cloves by the time of harvest (Fig. 3 D). Apical meristems of these plants differentiated into inflorescence at the time of lateral bud formation (Fig. 3 A). Thus, most of the plants with cloves bolted, as shown in Figure 3D. In contrast, plants less than a critical size did not produce lateral buds (clove initials). Apical meristems of these plants began swelling and produced single-cloved bulbs (Fig. 3 C).
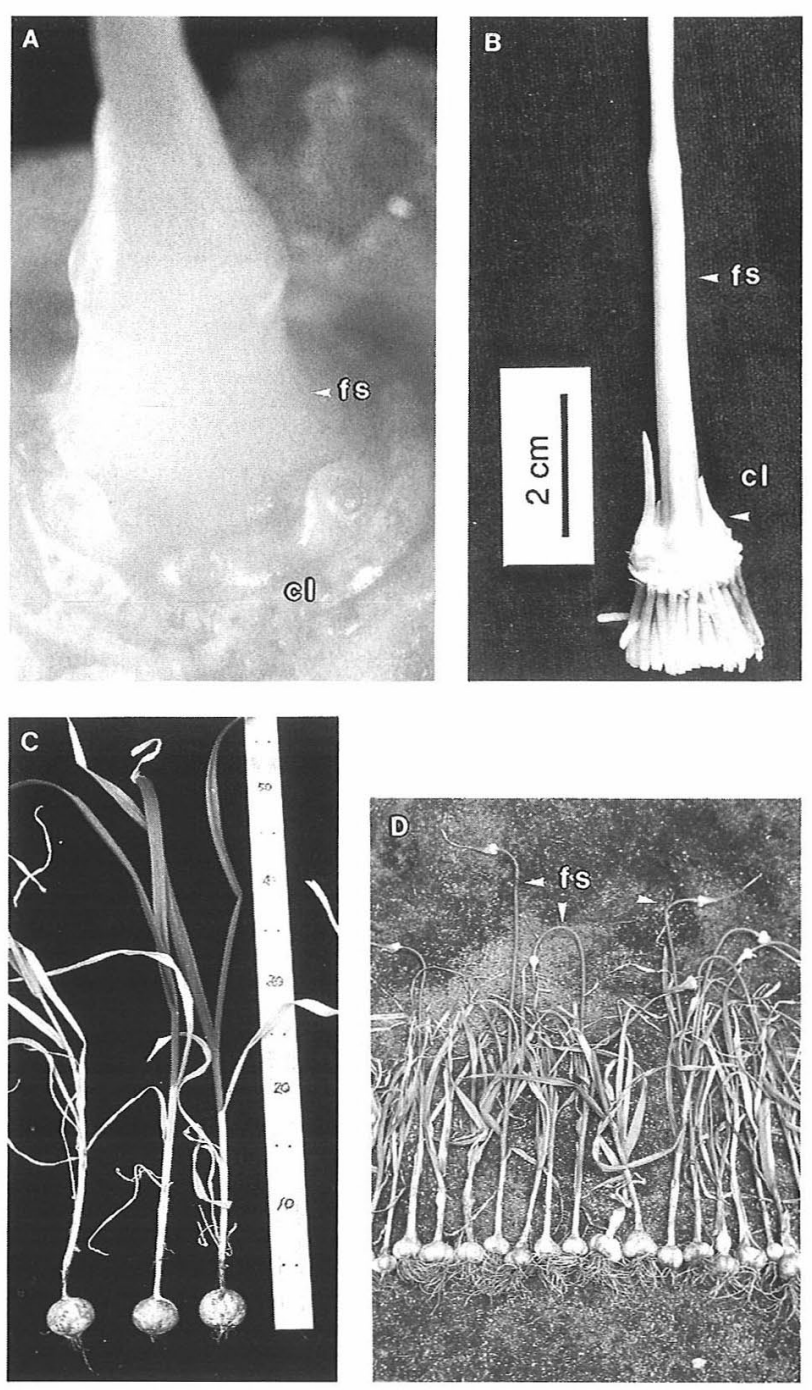

Fig. 3 Clove formation in cultivation of in vitro bulblet.

A. Initiation of clove initials (cl) and flower stalk (fs).

B. Flower stalk (fs) and cloves (cl) at the beginning of swelling of cloves.

C. Single clove bulb.

D. Multi-cloved bulb with bolting flower stalks (fs). 
3.4 Field propagation of bulbs and re-infection of viruses

Major viruses which infect garlic plants derived from meristem-tips are not known. Therefore, we collected data concerning re-infection processes of garlic viruses in farmer's fields for 5 years. Seed bulbs of garlic derived from meristem-tips culture were planted in five locations of farmer's fields and cultivated for 1 to 5 years, under standard cultural practices used in these districts. Ten bulbs were collected from each location after cultivation in these open fields, and again cultivated for one year in an isolated field (Misawa experimental field) for 8 months to investigate infected viruses. Plants exhibiting virus symptoms were scored in mid May when garlic plants are vigorously growing. Infecting viruses were also checked using both Western blots and RT-PCR techniques. Most of the plants obtained in the farmer's field after one-year cultivation were free of virus symptoms. LYSV, OYDV, and mite-borne viruses were not detected using RT - PCR. Virus symptoms were observed in $10 \%$ of plants after 2 years of cultivation at Tenmabayashi, in $30 \%$ and $50 \%$ of plants after 3 years of cultivation at Tohoku and Rokunohe, respectively. After 5 years of cultivation at Rokunohe, $70 \%$ of the plants were mosaic-diseased (Table 3). LYSV showed the highest rate, and infected plants exhibited mosaic symptoms. In this case, mite-borne viruses were also detected, at a frequency similar to that seen with LYSV. On the other hand, OYDV was rarely detected from meristem-tip derived plants. In contrast, none of the plants developed mosaic symptom, and only mite-borne virus was detected in $10 \%$ of the plants, in the case of a farmer's field in Misawa where garlic was cultivated in an isolated field.

\section{Discussion}

Diversified results on the efficiency of viruselimination through meristem-tip culture have been observed. It was reported that $94.4 \%$ of the garlic plants were healthy, based on visual inspection(Bhojwani, 1980). However, it was also reported that $11 \%$ (Conci and Nome, 1991) and 25\%(Walkey et al., 1987) of the plants were virusfree, based on indexing, using antisera. We showed that plants without mosaic symptoms (symptomless plants) can be obtained at rates of 98 and $93 \%$, when meristem-tips were excised without or with one leaf primordium, respectively. Thus, symptomless plants can be obtained at high frequencies through meristem-tip culture. In contrast, the ratio of plants that did not react with antiserum after
Western blot (antigen-less plants) accounted for 86 and $68 \%$, when meristem-tips were excised without or with one leaf primordium, respectively. Thus, the ratios obtained for healthy plants depend on evaluation methods, and discrepancies relate to the size of the meristem-tip cultured.

Normal, multi-cloved bulbs can be produced from bulblets in the first year of cultivation. Actually, multi-cloved bulbs were obtained at rates of 34-35\%. Cloves were obtained with higher efficiency by nursery transplanting than by direct sowing. Vigorously growing plants, which showed more than $6 \mathrm{~mm}$ in column diameter on May 13 were efficiently obtained from $>150 \mathrm{mg}(>6.5 \mathrm{~mm})$ bulblets, and these larger plants produced multicloved bulbs. Hwang and coworkers (Hwang et al., 1986) reported the production of single cloved bulbs, from $\phi>3 \mathrm{~mm}$ bulblets. Walkey and coworkers (Walkey et al., 1987) obtained multicloved bulbs using plantlet derived-transplantings, they transplanted nurseries after virus-indexing in the greenhouse. Clove formation in cultivation of the bulblets depended on the size of the plants at the time when clove formation was initiated. Therefore, further optimization of conditions for field cultivation and clove formation is feasible.

$\mathrm{Re}$-infection of viruses in farmer's fields is a major obstacle for utilization of meristem-tip derived seed bulbs. Most of meristem-tip derived garlic exhibited mosaic symptoms after 3 to 4 years cultivation in open fields(Ogawa et al., 1976; Hwang et al., 1986). In our work, the number of infected plants gradually increased year by year and over $60 \%$ of plants showed mosaic-disease symptoms after five years of cultivation. Frequency of re -infection was lower than previously reported, presumably because of cool climate in Aomori. LYSV and mite-borne viruses were detected at a similar rate. We reported that LYSV, mite-borne viruses and OYDV were found in 70-100\%, 0$40 \%$ and $0-25 \%$ of local garlic plants, respectively (Takaichi et al., 1998). LYSV was thought to be a major virus which causes disease symptoms in Aomori prefecture. Patterns and rates of infection of LYSV and OYDV to garlic from meristem-tips are consistent with their occurrence in traditional garlic. In contrast, mite-borne viruses were infected at higher rates than their previously reported occurrence. Plants infected by both LYSV and miteborne viruses might had been discarded through traditional practices of garlic cultivation. LYSV and OYDV are transmitted by aphids present in the fields, whereas mite-borne viruses are considered to be transmitted by mites, mainly during storage periods of seed bulbs. In a farmer's open, isolated 
field in Misawa (300-m isolation), no LYSV and only $10 \%$ of mite-borne virus was detected after two years of field propagation. Thus, prevention of re-infection of viruses to seed bulbs of garlic may be feasible through simple isolation.

\section{Acknowledgment}

We thank Dr. Tsuji for encouragement and practical advice, Ms. Chikahisa for excellent technical assistance, Drs. Yanagino and Chu of Aomori Experimental station for field and horticultural crops and Drs. Niwata, Higuchi, Yamashita and Hasegawa of Aomori Green Biocenter for many useful discussions and advice.

\section{References}

Abiko, K., Watanabe, Y., Nishi, Y., 1980. Bull. Veg. Ornm. Crops Res. Stn. Ser. A, 7:139-147.

Bhojwani, S. S., 1980. Scientia Hort. 13:47- 52.

Conci, V. C., Nome, S. F., 1991. J. Phytopathol. 132:186192.

Hwang, K.M., Chung, J.H., Park, S.K., 1986. Res. Rep. RDA. (Hort) 28:24- 31.

Kobayashi, K., and Rabinowicz, P., 1996. Arch. Virol. 141:2277-2287.

Lee, W. M., Yamazaki, S., Osaki, T., Inoue, T., 1979. Ann. Phytopath. Soc. Japan. 45:727-734.

Matsubara, S., Chen, D., 1989. HortScience 24:676-679.

Mikami, T., 1984. Kenkyu journal, Norin suisan gijutsu, 7:17-20. (In Japanese).
Mori, N., 1988. Nogyo oyobi Engei 63:169-174. (In Japanese).

Nagakubo, T., Nagasawa, A., Ohkawa, H., 1993. Plant Cell Tiss. Org. Cult. 32:175-183.

Nagakubo, T., Kubo, M., Oeda, K., 1994. Phytopathology 84:640-645.

Nagakubo, T., Takaichi, M., Oeda, K., 1997. Biotechnology in Agriculture and Forestry 39:5- 19.

Novak, F. J., 1990. In "Onions and Allied crops" (eds. by H. D. Rabinowitch, and J. L. Brewster) Vol. 1., p. 233 250, CRC Press, Florida.

Ogawa, T., Matsubara, N., Mori, N., 1976. Nogyo oyobi Engei 51:551 - 554. (In Japanese).

Osawa, K., Sugawara, H., 1980. Bull. Dept. Breeding Veg. and Orn. Crops Res. Sta., Japan. 7:22-25. (In Japanese).

Pena-Igresias, A., Ayuso, P., 1982. Acta Hort. 127:183193.

Sumi, S., Tsuneyoshi, T., Furutani, H. 1993. J. Gen. Virol. 74:1879- 1885.

Takaichi, M., Yamamoto, M., Nagakubo, T., Oeda, K. 1998. Plant Disease 82:694- 698.

Takaichi, M., Nagakubo, T., Oeda, K. (in preparation).

van Dijk, P., Verbeek, M., Bos, L., 1991. Neth. J. P1. Path. 97:381- 399.

Walkey, D. G. A., Antill, D. N., 1989. J. Hort. Sci. 64:5360.

Walkey, D. G. A., Webb, M. J. W., Bolland, C. J., and Miller, A., 1987. J. Hort. Sci. 62:211-220.

Yamashita, K., Sakai, J., Harada, K., 1996. Ann. Phytopath. Soc. Jpn. 62:483-489. 